\title{
EXPERIENCING \\ MASCULINITY \\ IN THE CLASSROOM
}

\section{A reflection}

\section{Alice King}

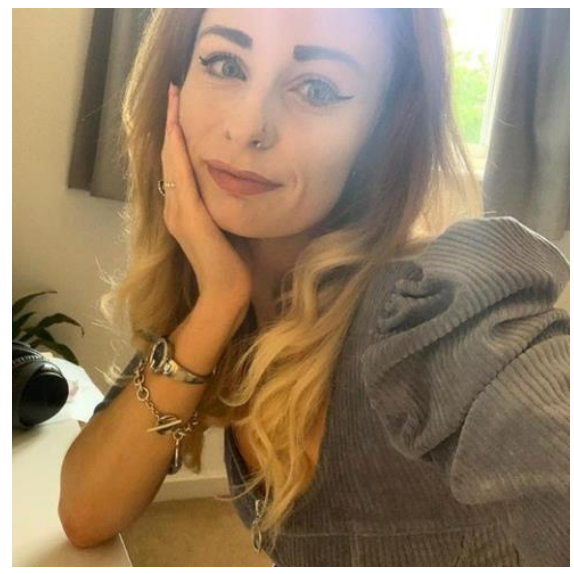

Lecturer and PhD Student, University of Warwick

Correspondence: alice.king@warwick.ac.uk

Twitter: @alice_king12

Alice's research is concerned with understanding student attitudes towards sexual violence and common sexual behaviours at elite institutions and situating these attitudes within broader discourses. Her work is informed by feminist and post-structural theories of power and gender. Alongside completing her PhD, Alice has recently taken up a lectureship at London Southbank University where she teaches a broad array of undergraduate law modules.

\section{Experiencing masculinity in the classroom}

Feminists have long encouraged researchers to reflect on their position and experiences as part of the research process (Letherby 2002). Here, I offer my reflection on my position as a young, white, cis-gendered woman in the classroom as a PGR and ECR teacher.

My research, outside of the classroom, focuses on elite universities gender norms, sexual violence. More recently I have taken to a focus on men and masculinities. Often, the 
result of this newer, emerging research interest has led to my research interests and teaching responsibilities becoming more entwined. Whilst teaching, I often find myself preoccupied with questions unrelated to the law and legal study. I ask myself:

\section{How are my students performing and producing their masculinities in the classroom space? Are they performing their masculinities in ways that we would expect? If not, what is different about their performances of masculinities and why is this important?}

This urge to question, and unpack, the behaviour of my students has been exacerbated as I now teach across two very different institutions - one 'elite' institution and another post-1992 institution with a vocational focus. Indeed, now I am often asking myself:

Why do students at different
institutions perform their masculinity
differently? What are the different ways
in which male students look to assert
their dominance across different
subsets of peers? Is it right to ground
these behaviours in a desire to assert
male dominance? Or is there more at
play at institutions where power and
prestige have less of a force in the day-
to-day operations of the institution?

These questions are not exhaustive, nor would it be possible to answer them completely within the space of a short reflection. Instead, here I am trying to start a conversation - as opposed to complete one.

\section{Laddishness and Lad Culture}

Existing literature concerned with men and masculinities within a teaching and learning context has often been centred around lad culture and or laddishness. Lad culture has been defined by several researchers, and these definitions tend to vary little and draw on similar ideas. Arguably the most arguably the most well-known definition of lad culture comes from the National Union of Students (NUS) commissioned study That's What She Said (2013), which was conducted by Alison Phipps. Although study itself was focused on experiences of lad culture, rather than engagement in it, Phipps suggested that lad culture can best be defined as:

\section{a pack mentality evident in activities such as sport and heavy alcohol consumption and 'banter' which is often sexist, misogynistic and homophobic (NUS 2013).}

When exploring why people might choose to behave laddishly, scholars have often suggested that the origins of this manifestation of laddism can be traced to the 'crisis of (hegemonic) masculinity' and neoliberalist notions of competition (Phipps 2016; Phipps and Young 2015a; Phipps and Young 2015b; Warin and Dempster 2007). White, middle-class men, once automatically entitled to privilege and power, perceive themselves to be facing the biggest loss because of inclusive politics and social policy. This prompts them in turn to reassert their dominance over female counterparts through laddish behaviours. Jackson and Sundaram suggest that young men in acting laddishly and being sexist and misogynistic are trying to reassert their dominance among their peers (Jackson and Sundaram, 2020).

From this literature, laddism is grounded in a loss of entitlement. We might expect, and indeed I expected, to see more overt practices of laddishness at elite institutions rather than post 1992 institutions.' Yet, surprisingly, this has not been my experience to date.

In fact, my experiences point towards a more complicated relationship between laddishness and learning in the classroom. In elite university spaces, my interactions with 
and experiences of male students has rarely involved laddishness, nor banter. On the contrary, male students in my seminars have often sought to overperform in class - to do extra reading and extra questions. Almost as if their goal is to trip you up, make you fumble over the law and perhaps have to admit that your expertise lies not with the difference between a lease and license. As the person on the receiving end of this, it often feels as though it is an assertion of dominance: a desire to make clear that although you are the teacher, they know more and can do better than you. This has often made for uncomfortable and difficult teaching experiences. The classroom often feels like a struggle - one in which you are expected to prove your knowledge and intelligence to those you are teaching.

In contrast, in post-1992 spaces, my interactions with and experiences of male students has more often involved laddishness - often specifically in the form of banter. Students are more jovial and less serious. If they are unprepared or unable to answer, they are likely to joke and laugh. Their banter was less about asserting one's dominance but more about deflecting a sense of insecurity. It is also less overtly sexist and not targeted at me as a female tutor. There is no sense that they want to assert dominance over you as the teacher nor that they might want to point out holes in your knowledge.

As a result, for me as a young ECR/PGR, the post-1992 space is the more comfortable of the two. I feel able to teach confidently, without fear of getting something wrong or misquoting the law, or having my authority challenged. Conversations are more organic and the space less hostile. Although I cannot say with certainty, I'd imagine I am a better teacher in this space too. I can devote my energy to making sure students are engaged and understanding the material as opposed to having to devote it to ensuring if there is a power struggle that I am, as the teacher, come out on top.

\section{References}

Jackson, Carolyn, and Vanita Sundaram, Lad Culture in Higher Education: Sexism, Sexual Harassment and Violence (Routledge, 2020)

Letherby Gayle. 2002. "Claims and

Disclaimers: Knowledge, Reflexivity and Representation in "Feminist Research". Sociological Research Online, 6 (4).

National Union of Students. 2013. “That's What She Said: women students' experiences of "lad culture in higher education"

Phipps, Alison and Isabel Young. 2015a. "'Lad Culture' in higher education: agency in the sexualisation debates". Sexualities 18 (4)
Phipps, Alison and Isabel Young. 2015b.

“Neoliberalisation and 'lad cultures' in higher education". Sociology 49 (2)

Phipps, Alison. 2017. “(Re)theorising laddish masculinities in higher education". Gender and Education 29 (7).

Warin, Jo and Steve Dempster. 2007. “The Salience of gender during the transition to Higher Education: male students' accounts of performed and authentic identities". British Educational Research Journal, 33 (6). 
'Here, I speak about laddism in the teaching and learning context. However, laddism transcends both the classroom and into more social spaces. In this discussion, I am suggesting is likely to be more pervasive across all aspects of university life. This includes the classroom but may well also spill over into other spaces.

To cite this article: Alice King. 2021. Experiencing Masculinity in the Classroom: a reflection. Journal of PGR Pedagogic Practice, 1, xx-xx. Available at: [url] 